\title{
Study of invitro thrombolytic activity of different extracts of Syzygium cumini
}

\author{
Kalyan Ranjan Dash¹, Jagan Kumar Das², Amiya Kumar Prusty ${ }^{3 *}$ \\ ${ }^{1,2}$ Student, ${ }^{3}$ Assistant Professor, Dept. of Pharmaceutical Biotechnology, Institute of Pharmacy and Technology, Salipur, Odisha, India \\ *Corresponding Author: Amiya Kumar Prusty \\ Email: amiyaprusty@gmail.com
}

\begin{abstract}
The present study was carried out to investigate the invitro thrombolytic activity of leaf and seed extracts of Syzygium cumini. The thrombolytic activity of different concentration of extracts was compared with the standard drug Streptokinase. The blood collected from human volunteers was taken as test sample for carrying out thrombolytic activity. 800ug/ml leaf extracts of Syzygium cumini showed the mean $\%$ of clot lysis as $57.07 \%+/-0.76,71.42 \%+/-0.75 \& 86.99 \%+/-1.33$ after incubation for $24 \mathrm{hrs}, 48 \mathrm{hrs}$, and $72 \mathrm{hrs}$ respectively at $37^{\circ} \mathrm{C}$. $800 \mathrm{ug} / \mathrm{ml}$ seed extracts of Syzygium cumini showed the mean $\%$ of clot lysis as $44.93 \%+/-2.49,66.58 \%+/-1.41, \& 83.32 \%+/-2.27$ after incubation for $24 \mathrm{hrs}, 48 \mathrm{hrs}$, and $72 \mathrm{hrs}$ respectively at $37^{\circ} \mathrm{C}$. The mean $\%$ clot lysis for the standard drug streptokinase was found to be $75.81 \%+/-0.71,88.54 \%+/-1.02$, and $93.04 \%+/-3.69$ after incubation for $24 \mathrm{hrs}, 48 \mathrm{hrs}$, and $72 \mathrm{hrs}$ respectively at $37^{\circ} \mathrm{C}$.
\end{abstract}

Keywords: Aqueous extract, Syzygium cumini, Control, Streptokinase, In-vitro thrombolytic activity.

\section{Introduction}

Thrombosis is defined as the formation of a clot inside a blood vessel, obstructing the flow of blood through the circulatory system. Blood clotting occurs as a result of complex interactions between activation of the coagulation factors, fibrinolytic systems, vascular endothelium, and of the cellular mechanisms, the interaction results in to a clot. ${ }^{1}$ Platelets play an important role in the maintenance of cardiovascular integrity, as they are used to control bleeding in the body parts after injury through formation of blood clots. $^{2}$ Arterial thrombosis due to uncontrolled platelet aggregation is critical leading to fatal disorders like deep vein thrombosis, pulmonary emboli, strokes and heart attacks. ${ }^{3}$ Thrombolytics are agents used to dissolve the fibrin of blood clot and thereby dissolve the formed clot inside blood vessel; therefore, thrombolytic agents are used in the treatment and/or prevention of cardiovascular thrombotic diseases by removing formed clots. Alteplase, antistreplase, streptokinase, urokinase and tissue plasminogen activator (tPA) are the mainly used drugs having thrombolytic activity to dissolve clots.

Some other anticoagulant drugs like heparins, vitamin $\mathrm{K}$ antagonists, and their derivatives have used for decades in the clinical treatment of thrombosis. But these drugs have there own demerrits. Though aspirin is one of the antithrombotic agent which still provides an effective secondary prevention of ischemic cardiovascular disorders, this drug can produce hemorrhagic events and upper gastrointestinal bleeding as major drawbacks. During the past years, several researches had been carried out for novel compounds having thrombolytic activity that can be used in treatment of disease. ${ }^{4}$ Most of the thrombolytic agents used now a day still have significant drawbacks, like large doses to be maximally effective, limited fibrin specificity, bleeding tendency and high cost. Due to drawbacks of available thrombolytic drugs, attempts are underway to develop improved recombinant variants of these drugs. Therefore plants can be explored as an alternative to the thrombolytic drugs. ${ }^{5}$ Therefore the leaves, seeds, twigs, stem, bark and underground parts of plants are most often used in traditional medicines for treatment of different diseases. ${ }^{6}$ Presently, in different parts of the world, more and more research has been carried out towards exploitation of higher plant products as novel chemotherapeutants due to their non phytotoxicity, systemicity, easy biodegradability and stimulatory nature. Phytochemicals like alkaloids, tannins, saponins, flavonoids etc are naturally occurring in the medicinal plants that have defense mechanism and protect the plant from various diseases and other environmental factors but recent research demonstrates that phytochemicals can have different pharmacologicl activity and used in treatment of humans against diseases. ${ }^{7}$

Syzygium cumini L. belongs to the family of Myrtaceae. It is a large evergreen tree of the Indian Subcontinent localy known as Jamun. It is having presence in Thailand, Philippines, Madagascar, and West Indies, East and West Africa and some subtropical regions including Florida, California, Algeria and Israel. The major phytoconstituents reported to be present in the plant extract contain vitamin $\mathrm{C}$, gallic acid, tannins, anthocyanins, cyanidin, petunidin, malvidinglucoside and other components. ${ }^{8}$ The stem bark of $S$. cumini contains butulinic acid, $\beta$-sitosterol, friedelin, epifriedelanol, D-glucoside, kaempterol-3-O-glucoside, quercetin, myricetin, astragalin etc. ${ }^{9}$ The seeds of $S$. cumini are used in traditional medicine as astringent, diuretic, hypoglycaemic, anti-inflammatory, antipyretic, psychopharmacological, hypolipidaemic, and antioxidant. Hence, in the present study invitro thrombolytic activity is going to be investigated by using different concentration of leaf and seed extracts of Syzygium cumini in search of a better thrombolytic agent. ${ }^{10}$

\section{Materials and Methods \\ Blood sample}

Whole blood $(3 \mathrm{ml})$ was drawn from healthy human volunteers $(n=10)$ without a history of oral contraceptive or anticoagulant therapy. From which $500 \mu \mathrm{l}(0.5 \mathrm{ml})$ of blood 
was transferred to each of the previously weighed micro centrifuge tubes to form clots.

\section{Syzygium cumini}

The leaves and seeds of syzygium cumini were collected from in and around the villages of Salipur, Cuttack, Odisha during the month of June.

\section{Preparation of aqueous extract of different parts of} syzygium cumini

Fresh different parts of Syzygium cumini plants were collected and washed properly with distilled water. The seed after separation from the berry and leaf sections were shade dried at room temperature for 15 days. Dried parts were uniformly grinded using mechanical grinder. The dried powder of plant material was extracted in distilled water. Ten grams of ground plant material was soaked in $100 \mathrm{ml}$ of distilled water in a round bottom flask and loaded in the heating mantle at a temperature of $70^{\circ} \mathrm{C}$ for 15 minutes for boiling. After 15 min temperature was reduced to $40^{\circ} \mathrm{C}$ and kept in that temperature for 1hour. Then the mixture was filtered using whatmann filter paper number 1. Each grounded plant materials were extracted separately. The dried extracts were weighed and stored in air tight container with necessary markings for identification and kept in refrigerator $\left(0-4^{\circ} \mathrm{C}\right)$ for future investigation. ${ }^{11}$

\section{Streptokinase (SK)}

Commercially available lyophilized Stukinase (Streptokinase) vial (Samarth pharmaceutical Ltd.) of 15, 00,000 I.U., was collected and $5 \mathrm{ml}$ sterile distilled water was added and mixed properly. This suspension was used as a stock from which $100 \mu \mathrm{l}(30,000$ I.U.) was used for in vitro thrombolysis study. ${ }^{12}$

\section{Procedure for clot lysis}

$3 \mathrm{ml}$ venous blood was drawn from healthy volunteers and distributed in five different labeled, pre weighed sterile micro centrifuge tube $(0.5 \mathrm{ml} /$ tube $)$ and incubated at $37^{\circ} \mathrm{C}$ for 45 minutes.

After clot formation, serum was completely removed without disturbing the clot using micro pipette and each tube having clot was again weighed to determine the total clot weight of every individual (clot weight $=$ weight of clot containing tube - weight of empty tube alone).

Various concentrations of leaf and seed crude extract of Syzygium cumini i.e. $200 \mu \mathrm{g} / \mathrm{ml}, 400 \mu \mathrm{g} / \mathrm{ml}, 600 \mathrm{ug} / \mathrm{ml}$ and $800 \mu \mathrm{g} / \mathrm{ml}$ were tested at various time intervals including; $24 \mathrm{hrs}, 48 \mathrm{hrs}$ and $72 \mathrm{hrs}$ duration of incubation at $37^{\circ} \mathrm{C}$ for maximum clot lysis. ${ }^{13} 100 \mu \mathrm{l}$ of streptokinase was added as a standard (30,000 I.U.) and $100 \mu \mathrm{l}$ of distilled water was added as a control to the preweighed blood clots along with different time of incubation i.e. $24 \mathrm{hrs}$, $48 \mathrm{hrs}$, and $72 \mathrm{hrs}$ at $37^{\circ} \mathrm{C}$. After incubation, fluid released was removed and tubes were again weighed to observe the difference in weight after clot disruption. Difference obtained in weight taken before and after clot lysis was expressed as percentage of clot lysis. The thrombolytic activities of all extracts were evaluated. The experiment was repeated 10 times with the blood samples of 10 volunteers.

\section{Statistical analysis}

To verify the results obtained the statistical analysis of the thrombolytic effects of the plant extracts were carried out by using SPS software and the data obtained is represented as mean \pm standard deviation. The statistical analysis used is paired t-test for calculation of significant difference between the control, standard and test results.

\section{Fibrinolytic properties}

Fibrin plate method was used to determine the fibrinolytic activity by using plasminogen free fibrin plate method. ${ }^{14}$ The media for fibrinolytic activity was prepared by adding fibrinogen solution made using $2.5 \mathrm{ml}$ of $1.2 \%(\mathrm{w} / \mathrm{v})$ human fibrinogen in $0.1 \mathrm{M}$ sodium phosphate buffer $(\mathrm{pH} 7.4)$ with $10 \mathrm{U}$ of thrombin solution, and $1 \%$ agarose. The fibrin plates were heated at $80^{\circ} \mathrm{C}$ for $30 \mathrm{~min}$ to eliminate other fibrinolytic factors. Paper disks of $6 \mathrm{~mm}$ diameter were prepared by Whatsman Filter paper number 1. The fibrinolytic activity was studied by dipping the paper discs in respective sample extract and carefully placed them on the plate and incubated at $35^{\circ} \mathrm{C}$ for $24 \mathrm{~h}$. Streptokinase (30,000 IU), phosphate buffer $(20 \mathrm{mM})$ were used as positive control and blank respectively. The fibrinolytic activity was determined by measuring the clear zone diameter formed around the paper disc at six different positions.

\section{Results}

\section{Thrombolytic activity of streptokinase}

$100 \mu \mathrm{l}$ of streptokinase the standard was added as a positive control (30,000 I.U.) and $100 \mu \mathrm{l}$ of distilled water was added as a control to the preweighed blood clots along with different time of incubation i.e. $24 \mathrm{hrs}, 48 \mathrm{hrs}$, and $72 \mathrm{hrs}$ at $37^{\circ} \mathrm{C}$ showed mean clot lysis of $75.81 \%+/-0.71,88.54 \%+/-$ 1.02 and $93.04 \%+/-3.69$ respectively (Table 1). Similarly the control distilled water was added to blood clot and after incubation i.e. $24 \mathrm{hrs}, 48 \mathrm{hrs}$, and $72 \mathrm{hrs}$ at $37^{\circ} \mathrm{C}$ showed mean clot lysis of $5.25 \%+/-0.49,11.70 \%+/-0.69$ and $19.47 \%+/-2.32$ espectively.

Table 1: In vitro-thrombolytic activity of control (water) and standard (Streptokinase):

\begin{tabular}{|c|c|c|}
\hline $\begin{array}{c}\text { Concentrations of } \\
\text { crude leaf extract }\end{array}$ & $\begin{array}{c}\text { Incubation } \\
\text { Time }\end{array}$ & $\begin{array}{c}\text { Clot Lysis \% } \\
\text { (Mean+/-SD) }\end{array}$ \\
\hline Standard & $24 \mathrm{hrs}$ & $75.81 *+/-0.71$ \\
\hline & $48 \mathrm{hrs}$ & $88.54 *+-1.02$ \\
\hline Control & $72 \mathrm{hrs}$ & $93.04 *+/-3.69$ \\
\hline & $24 \mathrm{hrs}$ & $5.25+/-0.49$ \\
\hline & $48 \mathrm{hrs}$ & $11.70+/-0.69$ \\
\hline & $72 \mathrm{hrs}$ & $19.47+/-2.32$ \\
\hline
\end{tabular}

* The result is significant at $p<0.01$

\subsection{Thrombolytic activity of Syzygium cumini}

When $100 \mu$ l of different concentration of Syzygium cumini aqueous preparation of leaf and seed extract was added to different blood clots, it showed a good thrombolytic activity as shown in Tale $1 \& 2$ comparable to the standard drug streptokinase. The aqueous preparation of syzygium cumini 
leaf extract showed more thrombolytic activity as compared to seed extract.

The $200 \mathrm{ug} / \mathrm{ml}$ leaf extract showed mean $\%$ clot lysis of $13.4+/-1.35,20.7+/-1.76 \& 35.6+/-1.50$ at incubation time of $24 \mathrm{hrs}, 48 \mathrm{hrs}$, and $72 \mathrm{hrs}$ resp at $37^{\circ} \mathrm{C}$. The $400 \mathrm{ug} / \mathrm{ml}$ leaf extract showed mean \% clot lysis of $26.42+/-1.25,42.91+/-$ $1.07 \& 57.26+/-2.00$ at incubation time of $24 \mathrm{hrs}, 48 \mathrm{hrs}$, and $72 \mathrm{hrs}$ resp at $37^{\circ} \mathrm{C}$. The $600 \mathrm{ug} / \mathrm{ml}$ leaf extract showed mean $\%$ clot lysis of $42.08+/-0.42,53.77+/-1.61 \& 69.06+/-0.76$ at incubation time of $24 \mathrm{hrs}, 48 \mathrm{hrs}$, and $72 \mathrm{hrs}$ resp at $37^{\circ} \mathrm{C}$. The $800 \mathrm{ug} / \mathrm{ml}$ leaf extract showed mean \% clot lysis of $57.07+/-$ $0.76,71.42+/-0.75 \& 86.99+/-1.33$ at incubation time of $24 \mathrm{hrs}, 48 \mathrm{hrs}$, and $72 \mathrm{hrs}$ resp at $37^{\circ} \mathrm{C}$. Similarly $200 \mathrm{ug} / \mathrm{ml}$ seed extract showed mean \% clot lysis of $11.08+/-0.58$, $20.97+/-0.59 \& 31.50+/-1.43$ at incubation time of $24 \mathrm{hrs}$, $48 \mathrm{hrs}$, and $72 \mathrm{hrs}$ resp at $37^{\circ} \mathrm{C}$. The $400 \mathrm{ug} / \mathrm{ml}$ seed extract showed mean \% clot lysis of $26.42+/-1.25,42.91+/-1.07 \&$ $57.26+/-2.00$ at incubation time of $24 \mathrm{hrs}, 48 \mathrm{hrs}$, and $72 \mathrm{hrs}$ resp at $37^{\circ} \mathrm{C}$. The $600 \mathrm{ug} / \mathrm{ml}$ seed extract showed mean $\%$ clot lysis of $35.40+/-0.71,53.25+/-0.91 \& 63.74+/-2.23$ at incubation time of $24 \mathrm{hrs}, 48 \mathrm{hrs}$, and $72 \mathrm{hrs}$ resp at $37^{\circ} \mathrm{C}$. The $800 \mathrm{ug} / \mathrm{ml}$ seed extract showed mean $\%$ clot lysis of $57.07+/-$ $0.76,71.42+/-0.75 \& 86.99+/-1.33$ at incubation time of 24hrs, $48 \mathrm{hrs}$, and $72 \mathrm{hrs}$ resp at $37^{\circ} \mathrm{C}$.

Table 2: In vitro-thrombolytic activity of aqueous Leaf extract of Syzygium cumini

\begin{tabular}{|l|c|c|}
\hline $\begin{array}{l}\text { Concentrations of } \\
\text { crude leaf extract }\end{array}$ & $\begin{array}{c}\text { Incubation } \\
\text { time }\end{array}$ & $\begin{array}{c}\text { Clot Lysis \% } \\
\text { (Mean+/-SD) }\end{array}$ \\
\hline \multirow{3}{*}{ 200ug/ml } & $24 \mathrm{hrs}$ & $13.4+/-1.35$ \\
\cline { 2 - 3 } & $48 \mathrm{hrs}$ & $20.7+/-1.76$ \\
\cline { 2 - 3 } & $72 \mathrm{hrs}$ & $35.6+/-1.50$ \\
\hline \multirow{4}{400ug/ml}{} & $24 \mathrm{hrs}$ & $26.42+/-1.25$ \\
\cline { 2 - 3 } & $48 \mathrm{hrs}$ & $42.91+/-1.07$ \\
\cline { 2 - 3 } & $72 \mathrm{hrs}$ & $57.26+/-2.00$ \\
\hline \multirow{3}{*}{$00 u g / m l$} & $24 \mathrm{hrs}$ & $42.08^{*}+/-0.42$ \\
\cline { 2 - 3 } & $48 \mathrm{hrs}$ & $53.77 *+/-1.61$ \\
\cline { 2 - 3 } & $72 \mathrm{hrs}$ & $69.06 *+/-0.76$ \\
\hline \multirow{3}{*00ug/ml}{} & $24 \mathrm{hrs}$ & $57.07 *+/-0.76$ \\
\cline { 2 - 3 } & $48 \mathrm{hrs}$ & $71.42 *+/-0.75$ \\
\cline { 2 - 3 } & $72 \mathrm{hrs}$ & $86.99 *+/-1.33$ \\
\hline
\end{tabular}

* The result is significant at $p<0.01$

Table 3: In vitro-thrombolytic activity of aqueous seed extract of Syzygium cumini

\begin{tabular}{|l|c|c|}
\hline $\begin{array}{l}\text { Concentrations of } \\
\text { crude seed extract }\end{array}$ & $\begin{array}{c}\text { Incubation } \\
\text { time }\end{array}$ & $\begin{array}{c}\text { Clot lysis \% } \\
\text { (Mean+/-SD) }\end{array}$ \\
\hline \multirow{2}{*}{ 200ug/ml } & $24 \mathrm{hrs}$ & $11.08+/-0.58$ \\
\cline { 2 - 3 } & $48 \mathrm{hrs}$ & $20.97+/-0.59$ \\
\cline { 2 - 3 } & $72 \mathrm{hrs}$ & $31.50+/-1.43$ \\
\hline \multirow{4}{400ug/ml}{} & $24 \mathrm{hrs}$ & $21.45+/-0.57$ \\
\cline { 2 - 3 } & $48 \mathrm{hrs}$ & $43.43+/-0.93$ \\
\cline { 2 - 3 } & $72 \mathrm{hrs}$ & $54.63+/-2.37$ \\
\hline \multirow{2}{*}{$00 u g / m l$} & $24 \mathrm{hrs}$ & $35.40^{\#}+/-0.71$ \\
\cline { 2 - 3 } & $48 \mathrm{hrs}$ & $53.25^{\#}+/-0.91$ \\
\cline { 2 - 3 } & $72 \mathrm{hrs}$ & $63.74^{\#}+/-2.23$ \\
\hline $\mathbf{8 0 0 u g / m l}$ & $24 \mathrm{hrs}$ & $44.93^{\#}+/-2.49$ \\
\hline
\end{tabular}

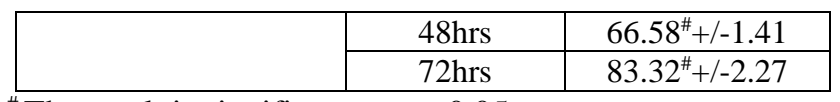

${ }^{\#}$ The result is significant at $p<0.05$

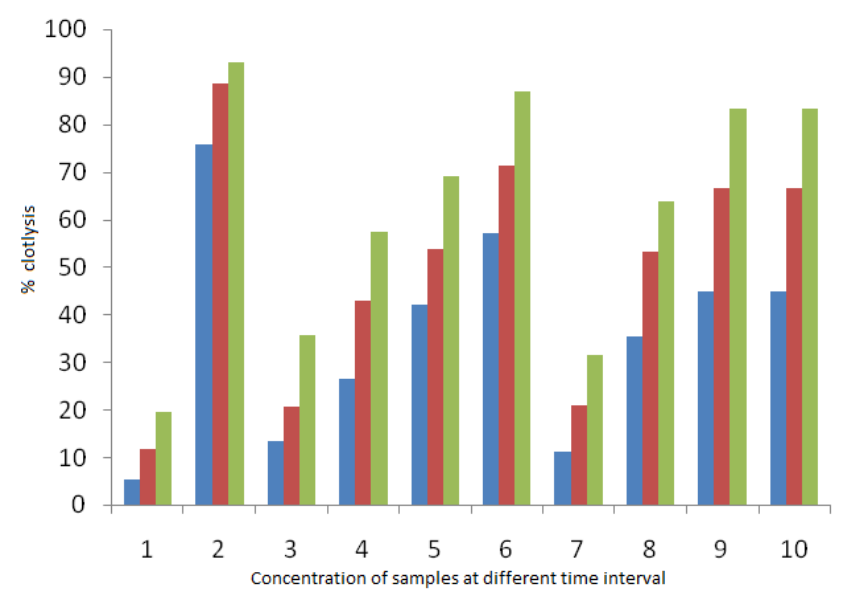

Fig.1: Bar diagram of in vitro-thrombolytic activity

1. Control at $24 \mathrm{hrs}, 48 \mathrm{hrs}$, and $72 \mathrm{hrs}$ of incubation

2. Standard at $24 \mathrm{hrs}, 48 \mathrm{hrs}$, and $72 \mathrm{hrs}$ of incubation

3. $200 \mathrm{ug} / \mathrm{ml}$ leaf extract at $24 \mathrm{hrs}, 48 \mathrm{hrs}$, and $72 \mathrm{hrs}$ of incubation

4. $400 \mathrm{ug} / \mathrm{ml}$ leaf extract at $24 \mathrm{hrs}, 48 \mathrm{hrs}$, and $72 \mathrm{hrs}$ of incubation

5. $600 \mathrm{ug} / \mathrm{ml}$ leaf extract at $24 \mathrm{hrs}, 48 \mathrm{hrs}$, and $72 \mathrm{hrs}$ of incubation

6. $800 \mathrm{ug} / \mathrm{ml}$ leaf extract at $24 \mathrm{hrs}, 48 \mathrm{hrs}$, and $72 \mathrm{hrs}$ of incubation

7. $200 \mathrm{ug} / \mathrm{ml}$ seed extract at $24 \mathrm{hrs}, 48 \mathrm{hrs}$, and $72 \mathrm{hrs}$ of incubation

8. $400 \mathrm{ug} / \mathrm{ml}$ seed extract at $24 \mathrm{hrs}, 48 \mathrm{hrs}$, and $72 \mathrm{hrs}$ of incubation

9. $600 \mathrm{ug} / \mathrm{ml}$ seed extract at $24 \mathrm{hrs}, 48 \mathrm{hrs}$, and $72 \mathrm{hrs}$ of incubation

10. $800 \mathrm{ug} / \mathrm{ml}$ seed extract at $24 \mathrm{hrs}, 48 \mathrm{hrs}$, and $72 \mathrm{hrs}$ of incubation

\section{Fibrinolytic properties}

The diameter of clear zone measuring $6.4+/-0.7 \mathrm{~mm}$ and 6.3 $+/-0.7 \mathrm{~mm}$ were formed around the disc loaded with leaf and seed extract respectively. Whereas in the positive control (disc having streptokinase) a zone measuring about $6.86+/-0.05 \mathrm{~mm}$ diameter was observed. There was no zone formation in the blank. This indicates the specificity of the plant extract towards fibrinogen.

\section{Conclusion}

The different concentration of leaf and seed extracts of Syzygium cumini can be used to design anti thrombotic agent due to its moderate thrombolytic activity as compared to the standard drug streptokinase. Further research work is needed to isolate the bioactive components or secondary metabolites present in the extract that will provide more precise and accurate thrombolytic activity. The present in vitro thrombolytic study demonstrated that information of 
using plants in folk medicine can be as effective as modern medicine without the side effects of synthesised chemical medicine. The herbal preparation containing leaf extract of plant Syzygium cumini can be used effectively as a thrombolytic agent instead of using chemically prepared thrombolytic drugs to avoid threatened side effects.

\section{Source of funding}

None.

\section{Conflict of interest}

None.

\section{References}

1. Sultana I, Noor MA, Barua J, Mahmood A, Das MC, Ibrahim MM, Chowdhury MM et al. In-vitro ntiatherothrombosis activity of four Bangladeshi plants. Int J Green Pharm 2012;6(1):5-8

2. May AE, Seizer P, and Gawaz M. Platelets: inflammatory firebugs of vascular walls. Arteriosclerosis, Thromb, Vasc Biol 2008;28(3):s5-s10.

3. Davies MJ and Thomas AC. Plaque fissuring the cause of acute myocardial infarction, sudden ischemic death, and crescendo angina. Br Heart J 1985;53(4):363-73.

4. Lau A J, Toh DF, Chua TK, Pang YK, Woo SO, and Koh HL. Antiplatelet and anticoagulant effects of Panax notoginseng: comparison of raw and steamed Panax not ginseng with Panax ginseng and Panax quinquefolium. J Ethnobiol Pharmacol 2009; 125(3):380-6.

5. De Medeiros JMR, Macedo M, Contancia JP, Nguyen C, Cunningham G, Miles DH. Antithrombin activity of medicinal plants of the Azores. J Ethnopharmacol 2000,72:157-65.

6. Elumalai A, Eswariah CM, Chowdary V, Kumar R, Anusha M, Naresh K. Screening of Thrombolytic Activity of Bougainvillea glabra Leaves Extract by In-Vitro. Asian J Res Pharm Sci 2012;2(4):134-6.
7. Krishnaiah D, Sarbatly R and Bono A Phytochemical antioxidants for health and medicine A move towards nature. Biotechnol Molecul Biol Rev 2007;1:97-104.

8. Bhatia IS and Bajaj KL. Chemical constituents of the seeds and bark of Syzygium cumini, Planta Medica 1975;28:346-52.

9. Ghosh KD, Chakraborty GK, Chatterjee AKN, Chaudhury and $\mathrm{Pal}$ M. Studies on anti-inflammatory and antipyretic activities of Syzygium cumini Linn seeds. IRCS Med Sci Biochem 1985;13:340-1.

10. Mahapatra PK, Pal M, Chaudhuri AKN, Chakraborty D and Basu A. Preliminary studies on glycaemic effect of Syzigium cumini seeds. IRCS Med Sci Biochem 1985;13:631-2.

11. Prusty AK, Ghosh T, Sahu S K. Anthelmintic, antimicrobial and antipyretic activity of various extracts of Clerodendrum infortunatumlinn. Leaves Ori Pharm Exper Med 2008;8(4):374-9.

12. Zhiguang L., Jiazeng L, Guangshen Z, Cunji G. Basic and clinical study on the antithrombotic mechanism of glycosaaminoglycan extracted from sea cucumber. Chin Med J 2000;113(8):706-11.

13. Elumalai A, Eswariah CM, Chowdary V, Kumar R, Anusha M, Naresh K. Screening of Thrombolytic Activity of Bougainvillea glabra Leaves Extract by In-Vitro, Asian J Res Pharm Sci 2012;2(4):134-6.

14. Asep A. Prihanto, Darius, Muhamad Firdaus. Proteolytic and fibrinolytic activities of halophilic lactic acid bacteria from two Indonesia fermented foods 2013;2(5):2291-3.

How to cite this article: Dash KR, Das JK, Prusty AK. Study of invitro thrombolytic activity of different extracts of Syzygium cumini. Indian J Pharm Pharmacol 2019;6(3):7982. 